Biogeosciences Discuss., https://doi.org/10.5194/bg-2018-461

Manuscript under review for journal Biogeosciences

Discussion started: 6 November 2018

(c) Author(s) 2018. CC BY 4.0 License.

\title{
Alkalinity and nitrate concentrations in calcareous watersheds: Are they linked, and is there an upper limit to alkalinity?
}

\author{
Beat Müller ${ }^{1}$, Joseph S. Meyer ${ }^{2,3}$, René Gächter ${ }^{1}$ \\ ${ }^{1}$ Eawag, Swiss Federal Institute of Aquatic Science and Technology, CH-6047 Kastanienbaum, Switzerland \\ $5 \quad{ }^{2}$ Department of Chemistry and Geochemistry, Colorado School of Mines, Golden, Colorado 80401 USA \\ ${ }^{3}$ Applied Limnology Professionals LLC, Golden, Colorado 80401 USA \\ Correspondence to: Beat Müller (beat.mueller@eawag.ch)
}

\begin{abstract}
Data from aquifers in calcareous watersheds in Switzerland demonstrate that alkalinity initially increases approximately in proportion to nitrate $\left(\mathrm{NO}_{3}^{-}\right)$concentration in the groundwater and eventually approaches an apparent maximum of approximately $8 \mathrm{mmol} \mathrm{L}^{-1}$ at high $\mathrm{NO}_{3}{ }^{-}$concentrations. This close positive relationship between alkalinity and $\mathrm{NO}_{3}{ }^{-}$concentration appears to be predominantly a result of three processes: (i) mineralization of organic nitrogen $(\mathrm{N}$ ) fertilizer, (ii) exchange of $\mathrm{OH}^{-}$and $\mathrm{H}^{+}$during the uptake of $\mathrm{NO}_{3}^{-}$or ammonium $\left(\mathrm{NH}_{4}{ }^{+}\right)$, and (iii) $\mathrm{CO}_{2}$ released by roots as a result of fertilizer-stimulated plant growth. Atmospheric deposition of $\mathrm{N}$ and strong acids $\left(\mathrm{H}_{2} \mathrm{SO}_{4}\right.$ and $\left.\mathrm{HNO}_{3}\right)$ play a minor role. We suggest that the asymptotic approach to a maximum groundwater alkalinity at $\mathrm{NO}_{3}{ }^{-}$concentrations exceeding 0.25 mmol L $\mathrm{L}^{-1}$ may be caused by (i) a maximum possible areal crop production at excessive $\mathrm{N}$ fertilization and (ii) an increasing $\mathrm{CO}_{2}$ loss to the atmosphere due to the increasing $\mathrm{CO}_{2}$ production in the soil. Thus, we estimate that the fertilizer-intensive agriculture of Switzerland generates an annual flux from the soil to the atmosphere of at least $0.26 \mathrm{Mt} \mathrm{CO}_{2} \mathrm{a}^{-1}$. This analysis provides a general understanding and quantitative prediction of steady-state groundwater $\mathrm{NO}_{3}{ }^{-}$concentration; equilibrium groundwater alkalinity, $\mathrm{pH}$, and $\mathrm{pCO}_{2}$; and soil $\mathrm{CO}_{2}$ emissions to the atmosphere based on quantitative and qualitative information on the supply of $\mathrm{N}$ and acidity to the soil by atmospheric deposition and $\mathrm{N}$ fertilization. The positive correlation between alkalinity and $\mathrm{NO}_{3}{ }^{-}$concentration in groundwaters persists in rivers and lakes. However, due to the diffusive loss of $\mathrm{CO}_{2}$ to the atmosphere, subsequent precipitation of calcite, dilution with surface water, input of wastewater discharges and $\mathrm{NO}_{3}{ }^{-}$consumption by aquatic photoautotrophs, the correlation is less distinct.
\end{abstract}

\section{Introduction}

To enhance crop production, farmers supply nitrogen $(\mathrm{N})$ in the form of inorganic and organic fertilizers (Walworth, 2013) and/or manure to fields. Because nitrification [the oxidation of ammonium $\left(\mathrm{NH}_{4}{ }^{+}\right)$to nitrate $\left(\mathrm{NO}_{3}{ }^{-}\right)$] of reduced-N compounds produces protons $\left(\mathrm{H}^{+}\right)$that can dissolve carbonate minerals (Equations S-1 to S-5 and S-13 to S-17 in SI Table $\mathrm{S} 1$ ), the effects of $\mathrm{N}$-fertilizers on dissolved inorganic carbon (DIC) concentrations and fluxes in lotic systems have been investigated (Semhi et al., 2000; Raymond and Cole, 2003; Raymond et al., 2008; Barnes and Raymond, 2009; Kaushal et al., 2013; Müller et al., 2016). Additionally, the potential for a resulting release of $\mathrm{CO}_{2}$ to the atmosphere and its consequences for global climate change have been of special concern (West and McBride, 2005; Perrin et al., 2008; Li et al., 2013).

Alkalinity is a measure of the acid-neutralizing capacity of water. In freshwater systems, it is generally defined as:

$$
\text { Alkalinity }\left(\text { as mmol L }{ }^{-1}\right)=\left[\mathrm{HCO}_{3}^{-}\right]+2\left[\mathrm{CO}_{3}^{2-}\right]+\left[\mathrm{OH}^{-}\right]-\left[\mathrm{H}^{+}\right]
$$

where the brackets indicate concentrations of the designated ions (Stumm and Morgan, 1996). At circumneutral pH, bicarbonate ion $\left(\mathrm{HCO}_{3}{ }^{-}\right)$is the major component of alkalinity, with only minor contributions from carbonate $\left(\mathrm{CO}_{3}{ }^{2-}\right)$ and 
Biogeosciences Discuss., https://doi.org/10.5194/bg-2018-461

Manuscript under review for journal Biogeosciences

Discussion started: 6 November 2018

(c) Author(s) 2018. CC BY 4.0 License.

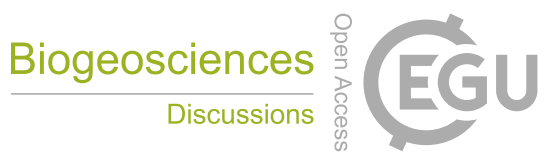

hydroxyl $\left(\mathrm{OH}^{-}\right)$ions. In calcareous watersheds, alkalinity originates mainly from the dissolution of carbonate minerals [e.g., calcite $\left(\mathrm{CaCO}_{3}\right)$ and dolomite $\left(\mathrm{Ca}_{\mathrm{x}} \mathrm{Mg}_{(1-\mathrm{x})} \mathrm{CO}_{3}\right)$ ] either by i) protons, which are generated by dissociation of strong mineral acids [e.g., nitric $\left(\mathrm{HNO}_{3}\right)$ or sulfuric $\left(\mathrm{H}_{2} \mathrm{SO}_{4}\right)$ ], or ii) by carbonic acid $\left(\mathrm{H}_{2} \mathrm{CO}_{3}\right)$ that is formed by the solvation of biogenic $\mathrm{CO}_{2}$ in water (Equations 2 and 3).

5

$$
\begin{aligned}
& \mathrm{CaCO}_{3}+\mathrm{H}^{+}=\mathrm{Ca}^{2+}+\mathrm{HCO}_{3}^{-} \\
& \mathrm{CaCO}_{3}+\mathrm{H}_{2} \mathrm{CO}_{3}=\mathrm{Ca}^{2+}+2 \mathrm{HCO}_{3}^{-}
\end{aligned}
$$

Therefore, in calcareous soils, in-soil production of $\mathrm{CO}_{2}$ (e.g., due to root respiration and heterotrophic mineralization of organic matter) and/or generation of protons by nitrification result in an increased alkalinity concentration. In contrast, in the absence of carbonate minerals, alkalinity is expected to decrease in proportion to the amount of nitrification and in-soil $\mathrm{CO}_{2}$ production (Perrin et al., 2008).

Changes in alkalinity can be of importance to the global carbon budget. For example, the alkalinity export of the Mississippi River (USA) to the Gulf of Mexico increased between 1950 and 2000, in excess of the simultaneously increasing water discharge (Raymond and Cole, 2003). West and McBride (2005) estimated 38\% of the $\mathrm{HCO}_{3}{ }^{-}$transported by the Mississippi River originated from calcite dissolution induced by $\mathrm{HNO}_{3}$. Similarly, Semhi et al. (2000), Perrin et al. (2008), Probst (1986) and Brunet et al. (2011) have attributed increasing alkalinity observed in French rivers to nitrification of N-fertilizers, and Guo et al. (2010) observed increased soil acidity as a consequence of the increasing use of N-fertilizers in China.

Apart from the increasing partial pressure of $\mathrm{CO}_{2}\left(\mathrm{pCO}_{2}\right)$ in the atmosphere (NOAA, 2017), increasing soil temperature (Zobrist et al., 2018) and changes in runoff, a variety of factors may affect groundwater and thus riverine alkalinity (Raymond et al., 2008). Those factors include (i) agricultural practices such as fertilization and liming (Müller et al., 2016; West and McBride, 2005; Oh and Raymond, 2006), (ii) mineral-acid load originating from atmospheric deposition (e.g., $\mathrm{HNO}_{3}$ [Equation S-6 in SI Table S1] and $\mathrm{H}_{2} \mathrm{SO}_{4}$ ), (iii) changes in microbial activity, (iv) acid mine drainage (Kaushal et al., 2013), and (v) sewage effluents (Barnes and Raymond, 2009). Because N plays a leading role in many of these interactions with soil water, groundwater and surface waters globally, and in view of the approximately five-fold increase of anthropogenic reactive $\mathrm{N}$ since 1960, with uncertain consequences, Battye et al. (2017) posed the question "Is nitrogen the next carbon?".

In this study, we

- present data from extensive groundwater and surface-water monitoring programs in calcareous agricultural Swiss watersheds demonstrating a strong linkage between alkalinity and $\mathrm{NO}_{3}{ }^{-}$concentrations,

- identify agricultural $\mathrm{N}$ fertilization fueling terrestrial primary production as the main driving force linking the two constituents in ground and surface waters.

- explain why alkalinity reaches an apparent upper limit at elevated $\mathrm{NO}_{3}{ }^{-}$concentrations in groundwater, and

- estimate the contributions of the Swiss farming activities to the global $\mathrm{CO}_{2}$ accumulation and to the alkalinity load of downstream surface waters.

\section{Methods}

Aquifer and surface waters considered in this study are described in Table 1. At atmospheric $\mathrm{pCO}_{2}$ ranging from $10^{-3.5}$ to $10^{-}$

${ }^{3.4} \mathrm{~atm}$ (the condition from approximately 1959 to present; NOAA, 2017) and in the absence of acids other than $\mathrm{H}_{2} \mathrm{CO}_{3}$, an

40 alkalinity concentration of $1.42 \mathrm{mmol} \mathrm{L}^{-1}$ and a $\mathrm{pH}$ of 8.24 would be expected in water draining a hypothetically $\mathrm{N}$-free (and thus sterile) calcareous soil, assuming a groundwater temperature of $8{ }^{\circ} \mathrm{C}$. Therefore, to avoid potentially confounding 
Biogeosciences Discuss., https://doi.org/10.5194/bg-2018-461

Manuscript under review for journal Biogeosciences

Discussion started: 6 November 2018

(c) Author(s) 2018. CC BY 4.0 License.

results from waters not in considerable contact with carbonates, we included in this analysis only waters originating from calcareous watersheds in which alkalinity exceeded $1 \mathrm{mmol} \mathrm{L}^{-1}$. If a titrated alkalinity was not reported, we approximated it as the reported molar concentration of $\mathrm{HCO}_{3}^{-}$.

In SI Table S1, we calculated theoretical molar $\Delta\left[\mathrm{HCO}_{3}{ }^{-}\right]: \Delta\left[\mathrm{NO}_{3}{ }^{-}\right]$and $\Delta([\mathrm{Ca}]+[\mathrm{Mg}]): \Delta\left[\mathrm{HCO}_{3}{ }^{-}\right]$ratios of chemical reactions

5 that likely occur in aquifers in the presence or absence of carbonate minerals. Additionally, we applied the geochemical speciation software ChemEQL Version 3.2 (Müller, 2015) to calculate $\mathrm{pH}$, alkalinity, $\mathrm{pCO}_{2}$, and $\mathrm{Ca}^{2+}$ concentrations in groundwater in equilibrium with calcite, into which we computationally titrated the $\mathrm{CO}_{2}, \mathrm{NO}_{3}{ }^{-}$, and $\mathrm{H}^{+}$resulting from the estimated loads of these compounds as used in Swiss agriculture. For these computational titrations, we neglected the exchange of soil/groundwater $\mathrm{CO}_{2}$ with the atmosphere and assumed equilibrium of the groundwater with soil $\mathrm{pCO}_{2}$. Initial conditions were as follows: temperature $=8{ }^{\circ} \mathrm{C}$, atmospheric $\mathrm{pCO}_{2}=0.0004$ atm in equilibrium with calcite, and $\mathrm{NO}_{3}{ }^{-}=0$ $\mathrm{mmol} / \mathrm{L}$, resulting in $\mathrm{pH}=8.24$ and alkalinity $=1.42 \mathrm{mmol} \mathrm{L}^{-1}$.

We calculated the $\mathrm{CO}_{2}$ saturation index of water as $\Omega_{\mathrm{CO}_{2}}=\mathrm{CO}_{2}(\mathrm{aq}) / \mathrm{CO}_{2}(\mathrm{~atm})$, where $\mathrm{CO}_{2}(\mathrm{aq})$ is the partial pressure of $\mathrm{CO}_{2}$ in the water (in atm) and $\mathrm{CO}_{2}(\mathrm{~atm})$ is the partial pressure of $\mathrm{CO}_{2}$ in the atmosphere (in atm). $\mathrm{CO}_{2}$ (aq) was calculated from the reported pH and alkalinity using Equation 6 in Müller et al. (2016). Reported concentrations of $\mathrm{Ca}^{2+}$, alkalinity, and $\mathrm{NO}_{3}{ }^{-}$ in lakes represent values observed at spring overturn averaged over all years of observation. Concentrations measured in rivers were averaged over the observation period. To produce conservative (i.e., minimum) estimates of $\Omega_{\mathrm{CO}_{2}}$, we assumed a value of $4 \times 10^{-4} \mathrm{~atm}\left(400 \mathrm{ppm}\right.$ ) for $\mathrm{CO}_{2}(\mathrm{~atm})$, which is the 2015 annual average in the Mauna Loa dataset (NOAA, 2017). The saturation index for calcite solubility was calculated as

$$
\Omega_{\text {calcite }}=\frac{\left\{\mathrm{Ca}_{2}^{+}\right\} \times\left\{\mathrm{CO}_{3}^{2-}\right\}}{K_{\text {calcite }}}
$$

where braces denote the ChemEQL-predicted chemical activity of $\mathrm{Ca}^{2+}$ or $\mathrm{CO}_{3}{ }^{2-}$, respectively, and $\mathrm{K}_{\text {calcite }}$ is the solubility product of calcite $\left(3.95 \times 10^{-9}\right.$ at $8{ }^{\circ} \mathrm{C}$ for groundwaters; $3.71 \times 10^{-9}$ at $15{ }^{\circ} \mathrm{C}$ for rivers). Ion activities were estimated with the Debye-Hückel approximation (Stumm and Morgan, 1996) for an ionic strength calculated from the sum of measured anions and cations. We calculated $\Omega_{\text {calcite }}$ only for the NAQUA-groundwaters and rivers, because $\mathrm{Ca}^{2+}$ concentrations were not available for lake waters and Zürich well waters.

Linear regressions of alkalinity versus $\mathrm{NO}_{3}{ }^{-}$concentration were performed with the statistical software program Stata Version 14 (StataCorp LLC, College Station, Texas, USA). Regression coefficients were inferred to be statistically significant when $\mathrm{p} \leq 0.05$.

\section{Results}

Alkalinity increased systematically with increasing $\mathrm{NO}_{3}{ }^{-}$concentrations in groundwater as well as in surface waters (Figures 1a and $1 \mathrm{~b}$ ). In the concentration range $0-0.25 \mathrm{mmol} \mathrm{NO}_{3}{ }^{-} \mathrm{L}^{-1}$, initial slopes of alkalinity versus $\mathrm{NO}_{3}{ }^{-}$concentration for groundwater and surface waters were 17.0 and $12.5 \mathrm{mmol}$ alkalinity $\mathrm{L}^{-1} / \mathrm{mmol} \mathrm{NO}_{3}^{-} \mathrm{L}^{-1}$, respectively (Table 2). The alkalinity-axis intercepts for the aquifer and surface waters were 2.44 and $1.74 \mathrm{mmol} \mathrm{L}^{-1}$, respectively (Table 2). At $\mathrm{NO}_{3}{ }^{-}$ concentrations exceeding $0.25 \mathrm{mmol} \mathrm{L}^{-1}$, the alkalinity versus $\mathrm{NO}_{3}{ }^{-}$slope decreased in the aquifer waters nearly 10 -fold to only $1.8 \mathrm{mmol}$ alkalinity $\mathrm{L}^{-1} / \mathrm{mmol} \mathrm{NO}_{3}{ }^{-} \mathrm{L}^{-1}$ (Table 2, Figure 1a). Because $\mathrm{NO}_{3}{ }^{-}$concentrations in the surface waters did not exceed $0.25 \mathrm{mmol} \mathrm{L}^{-1}$ (Figure 1b), we could not test for an analogous decrease of the slope at elevated $\mathrm{NO}_{3}{ }^{-}$concentrations in those waters. 
Biogeosciences Discuss., https://doi.org/10.5194/bg-2018-461

Manuscript under review for journal Biogeosciences

Discussion started: 6 November 2018

(c) Author(s) 2018. CC BY 4.0 License.

All waters were distinctly supersaturated with respect to atmospheric $\mathrm{CO}_{2}$ (up to 90 -fold in groundwaters and up to 11-fold in surface waters; Figure 1c). In the groundwaters, $\Omega_{\mathrm{CO}_{2}}$ increased rapidly as $\mathrm{NO}_{3}{ }^{-}$concentration increased from 0 to approximately $0.25 \mathrm{mmol} \mathrm{L}^{-1}$, but leveled-off at higher $\mathrm{NO}_{3}{ }^{-}$concentrations. In the surface waters, the trend of increasing $\Omega_{\mathrm{CO}_{2}}$ with increasing $\mathrm{NO}_{3}{ }^{-}$concentration was less distinct.

$5 \mathrm{As}^{-}{ }_{3}^{-}$concentration increased from 0 to $0.25 \mathrm{mmol} \mathrm{L}^{-1}$ in the groundwaters, $\mathrm{pH}$ tended to initially decrease but then leveled-off to approximately circumneutral values at higher $\mathrm{NO}_{3}{ }^{-}$concentrations (Figure 1d). In surface waters, $\mathrm{pH}$ ranged between 7.7 and 8.3, seemingly unrelated to the $\mathrm{NO}_{3}{ }^{-}$concentration (Figure 1d).

Ranging from 0.51 to 0.72 , the molar $([\mathrm{Ca}]+[\mathrm{Mg}])$ : $\left[\mathrm{HCO}_{3}^{-}\right]$ratio in the aquifer waters increased significantly as $\mathrm{NO}_{3}{ }^{-}$ concentration increased (slope $=0.079 / \mathrm{mmol} \mathrm{NO}_{3}^{-} \mathrm{L}^{-1}, \mathrm{p}<0.001$; Figure 1e). However, $\mathrm{NO}_{3}{ }^{-}$only accounted for $15 \%$ of

10 the variation of this ratio, suggesting that the majority of that variation depended on other factors. In the surface waters, the molar $([\mathrm{Ca}]+[\mathrm{Mg}]):\left[\mathrm{HCO}_{3}^{-}\right]$ratio ranged from 0.47 to 0.74 , without a trend analogous to the groundwater trend across the narrower range of $\mathrm{NO}_{3}{ }^{-}$concentrations in the surface waters (Figure 1f).

Contrary to most groundwaters being slightly undersaturated with respect to $\mathrm{CaCO}_{3}$ solubility $\left(\Omega_{\mathrm{CaCO}_{3}}=0.5-1.2\right.$; Figure $\left.1 \mathrm{~g}\right)$, 21 of the 22 river waters were supersaturated $\left(\Omega_{\mathrm{CaCO}_{3}}=1.2-8.4\right.$; Figure $\left.1 \mathrm{~g}\right)$.

15 Table 3 summarizes quantitative information about the various sources, sinks and pathways affecting the nitrogen budget of agricultural Swiss soils.

\section{Discussion}

\subsection{Aquifer Waters}

Because in all aquifer waters included in this analysis, (i) alkalinity exceeded the $1.42 \mathrm{mmol} \mathrm{L}^{-1}$ concentration expected in calcite-saturated, air-equilibrated water (Figure 1a), (ii) $\mathrm{pH}$ was considerably below the equilibrium-predicted value of 8.24 (Figure 1d), and (iii) $\mathrm{CO}_{2}$ concentrations were highly supersaturated (Figure 1c), the aquifer waters appear to be at least partially protected from contact with the atmosphere.

The equations in Table S1 show that the stoichiometric molar $([\mathrm{Ca}]+[\mathrm{Mg}]):\left[\mathrm{HCO}_{3}{ }^{-}\right]$ratio (i) equals 0.5 if carbonates are dissolved only as a result of interaction with $\mathrm{CO}_{2}$ (Equations S-19 and S-20), (ii) exceeds 0.5 if protons generated by nitrification or supplied by acid precipitation (Equations S-1 to S-6) contribute to the dissolution of carbonates (Equations S13 to S-18), and (iii) only slightly exceeds 0.5 (Equation S-21) if mineralization of organic matter (e.g., $\mathrm{C}_{106} \mathrm{H}_{263} \mathrm{O}_{110} \mathrm{~N}_{16} \mathrm{P}$, per Stumm and Morgan, 1996) is responsible for the carbonate dissolution. In all the groundwaters, the $([\mathrm{Ca}]+[\mathrm{Mg}])$ : $\left[\mathrm{HCO}_{3}{ }^{-}\right]$ratio slightly exceeded 0.5 (Figure 1e), suggesting that protons generated by in-soil nitrification or atmospheric deposition of acids must have contributed partly but not extensively to the generation of alkalinity in the groundwaters.

Despite high $\mathrm{pCO}_{2}$ in the groundwaters, those waters were only saturated to slightly undersaturated with respect to calcite solubility (Figure 1g), likely due to slow, diffusion-limited kinetics of calcite dissolution in the relatively quiescent soil water (Plummer et al. 1979).

\subsubsection{Origin of nitrogen in Swiss groundwaters}

35 Swiss legislation (Art. 14 Abs. 4 GSchG) restricts fertilization of crop fields and meadows to a maximum of $315 \mathrm{~kg} \mathrm{~N} \mathrm{ha}^{-1} \mathrm{a}^{-}$ ${ }^{1}\left(22.5 \mathrm{kmol} \mathrm{N} \mathrm{ha}^{-1} \mathrm{a}^{-1}\right)$. Table 3 and Figure 2 display that on average the total $\mathrm{N}$-fertilizer supply in Switzerland amounts to $206 \mathrm{~kg} \mathrm{~N} \mathrm{ha}^{-1} \mathrm{a}^{-1}$, seed adds $1 \mathrm{~kg} \mathrm{~N} \mathrm{ha}^{-1} \mathrm{a}^{-1}$, and atmospheric deposition contributes $26 \mathrm{~kg} \mathrm{~N} \mathrm{ha}^{-1} \mathrm{a}^{-1}$. On the other hand, only $148 \mathrm{~kg} \mathrm{~N} \mathrm{ha}^{-1} \mathrm{a}^{-1}$ are harvested as crops, resulting in an annual surplus of $85 \mathrm{~kg} \mathrm{~N} \mathrm{ha}^{-1} \mathrm{a}^{-1}$ to the soil. Because $\mathrm{N}$ does not accumulate in soils, this excess supply must result in losses to the groundwater $\left(22 \mathrm{~kg} \mathrm{~N} \mathrm{ha}^{-1} \mathrm{a}^{-1}\right)$ and to the atmosphere (63 
Biogeosciences Discuss., https://doi.org/10.5194/bg-2018-461

Manuscript under review for journal Biogeosciences

Discussion started: 6 November 2018

(c) Author(s) 2018. CC BY 4.0 License.

$\mathrm{kg} \mathrm{N} \mathrm{ha}^{-1} \mathrm{a}^{-1}$ ) by way of denitrification to $\mathrm{N}_{2}$ and/or $\mathrm{N}_{2} \mathrm{O}$ (Table 3). These inputs via fertilizer and atmospheric deposition and losses via crops and denitrification are summarized in Figure 2 (green arrows).

Because the annual groundwater generation rate is approximately $5000 \mathrm{~m}^{3} \mathrm{ha}^{-1} \mathrm{a}^{-1}$, we estimate an average groundwater $\mathrm{NO}_{3}{ }^{-}$ concentration of $22 \mathrm{~kg} \mathrm{~N} / 5000 \mathrm{~m}^{3} \mathrm{a}^{-1}=4.4 \mathrm{mg} \mathrm{N} \mathrm{L}^{-1}$ or $0.31 \mathrm{mmol} \mathrm{N} \mathrm{L}^{-1}$. This value is in the mid-range of the observed

$5 \mathrm{NO}_{3}{ }^{-}$concentrations in Figure 1.

\subsection{2 $\mathrm{CO}_{2}$ and acidity production by organic nitrogen fertilization}

As indicated in Table 3, in Switzerland most of the $\mathrm{N}$-fertilizer is applied as manure $\left(124 \mathrm{~kg} \mathrm{ha}^{-1} \mathrm{a}^{-1}\right)$ or by way of $\mathrm{N}$ fixation by Leguminosae $\left(32 \mathrm{~kg} \mathrm{ha}^{-1} \mathrm{a}^{-1}\right)$. Because approximately $20 \%$ of the $50 \mathrm{~kg} \mathrm{ha}^{-1} \mathrm{a}^{-1}$ of commercial N-fertilizer (i.e., $10 \mathrm{~kg} \mathrm{ha}^{-1}$ $\mathrm{a}^{-1}$ ) is supplied as urea (FOAG, 2016), a total of $166 \mathrm{~kg} \mathrm{~N} \mathrm{ha}^{-1} \mathrm{a}^{-1}$ or $11.9 \mathrm{kmol} \mathrm{N} \mathrm{ha}^{-1} \mathrm{a}^{-1}$ of organic $\mathrm{N}$ needs to be

10 mineralized annually before becoming bioavailable to plants. According to Equations S-5 and S-9 in SI Table S1, this mineralization produces totals of $11.9 \mathrm{kmol} \mathrm{NO}_{3}{ }^{-} \mathrm{ha}^{-1} \mathrm{a}^{-1}, 74.2 \mathrm{kmol} \mathrm{CO}_{2} \mathrm{ha}^{-1} \mathrm{a}^{-1}$ and $13.3 \mathrm{kmol} \mathrm{H}^{+} \mathrm{ha}^{-1} \mathrm{a}^{-1}$ (Fig. 2).

\subsubsection{Nitrate supply and acidity production due to the application of inorganic nitrogen fertilizer}

If the remaining $40 \mathrm{~kg} \mathrm{~N} \mathrm{ha}^{-1} \mathrm{a}^{-1}\left(2.86 \mathrm{kmol} \mathrm{N} \mathrm{ha}^{-1} \mathrm{a}^{-1}\right)$ of commercial fertilizer is applied as $\mathrm{NH}_{4} \mathrm{NO}_{3}$, its nitrification results

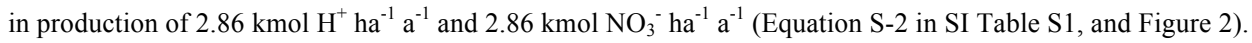

\subsubsection{Contribution of atmospheric nitrogen, acid and $\mathrm{CO}_{2}$ deposition to alkalinity production}

Strong acids in the atmosphere originate from combustion of fuels that generates $\mathrm{NO}_{\mathrm{x}}$ and $\mathrm{SO}_{2}$, which in contact with atmospheric water droplets oxidize to nitric and sulfuric acids. The average atmospheric deposition of acidity in Switzerland (Swiss plateau, Jura and pre-alps) is estimated to be $1.34 \mathrm{kmol} \mathrm{H}^{+} \mathrm{ha}^{-1} \mathrm{a}^{-1}$ (Graf Pannatier et al., 2011, their Table 3).

In Switzerland, approximately one-third of the $26 \mathrm{~kg} \mathrm{~N} \mathrm{ha}^{-1} \mathrm{a}^{-1}\left(1.86 \mathrm{kmol} \mathrm{N} \mathrm{ha}^{-1} \mathrm{a}^{-1}\right)$ of atmospheric deposited $\mathrm{N}$ consists of $\mathrm{NO}_{3}{ }^{-}$and two-thirds of $\mathrm{NH}_{4} \mathrm{OH}$ (NABEL, 2016). Nitrification of the latter in aerated soil or groundwater generates 1.24 kmol acidity $\mathrm{ha}^{-1} \mathrm{a}^{-1}$ (Equation S-1). Thus, the atmospheric acid deposition results in a total acidity load of $1.34+1.24=2.6$ kmol H $\mathrm{H}^{+} \mathrm{h}^{-1} \mathrm{a}^{-1}$.

At a $\mathrm{pCO}_{2}$ of $4 \times 10^{-4} \mathrm{~atm}$, approximately $10^{4} \mathrm{~m}^{3} \mathrm{ha}^{-1} \mathrm{a}^{-1}$ of rain water (FOMC, 2018) saturated with $\mathrm{CO}_{2}$ imports $0.26 \mathrm{kmol}$ $\mathrm{CO}_{2} \mathrm{ha}^{-1} \mathrm{a}^{-1}$ into the soil.

\subsubsection{Nitrate and acidity removal, and $\mathrm{CO}_{2}$ generation due to crop production}

In the process of $\mathrm{NO}_{3}{ }^{-}$assimilation, plants take up protons from the soil water in order to maintain charge balance (Haynes, 1990):

$$
106 \mathrm{CO}_{2}+16 \mathrm{NO}_{3}{ }^{-}+\mathrm{HPO}_{4}{ }^{2-}+122 \mathrm{H}_{2} \mathrm{O}+18 \mathrm{H}^{+} \Leftrightarrow\left\{\mathrm{C}_{106} \mathrm{H}_{263} \mathrm{O}_{110} \mathrm{~N}_{16} \mathrm{P}\right\}+138 \mathrm{O}_{2}
$$

where $\mathrm{C}_{106} \mathrm{H}_{263} \mathrm{O}_{110} \mathrm{~N}_{16} \mathrm{P}$ is a generic formula for organic matter (eg. Stumm and Morgan, 1996). Accordingly, an annual net primary production of $148 \mathrm{~kg} \mathrm{~N} \mathrm{ha}^{-1}\left(10.6 \mathrm{kmol} \mathrm{N} \mathrm{ha}^{-1} \mathrm{a}^{-1}\right)$ removes $11.9 \mathrm{kmol}_{\text {acidity ha }}{ }^{-1} \mathrm{a}^{-1}$ from the soil.

In addition, growth-dependent root respiration of crop plants can contribute $12-62 \%$ of the total in-soil $\mathrm{CO}_{2}$ production in temperate-zone crop fields, grasslands, and forests (Raich and Tufekcioglu, 2000). Using sunflower as a model plant, root respiration amounts to approximately $20 \%$ of net assimilation (Cheng et al., 2000). Assuming a molar C:N ratio of 106:16, the net assimilation of $10.6 \mathrm{kmol} \mathrm{N} \mathrm{ha}^{-1} \mathrm{a}^{-1}$ corresponds to a net carbon production of $70.2 \mathrm{kmol} \mathrm{C} \mathrm{ha}^{-1} \mathrm{a}^{-1}$ and thus suggests an in-soil $\mathrm{CO}_{2}$ production by crop plants of approximately $14 \mathrm{kmol} \mathrm{CO}_{2} \mathrm{ha}^{-1} \mathrm{a}^{-1}$.

4.1.6 Alkalinity and nitrate concentrations as well as $\mathrm{CO}_{2}$ emissions from the soil to the atmosphere are directly related to agricultural production 
Biogeosciences Discuss., https://doi.org/10.5194/bg-2018-461

Manuscript under review for journal Biogeosciences

Discussion started: 6 November 2018

(c) Author(s) 2018. CC BY 4.0 License.

Growth-dependent $\mathrm{N}$ uptake by crop plants increases with increasing $\mathrm{N}$ fertilization but eventually reaches a maximum at elevated concentrations in the soil solution (Baule, 1917). Mineralization of increasing amounts of manure stimulates growth-dependent $\mathrm{N}$ uptake that results in increased groundwater $\mathrm{NO}_{3}{ }^{-}$and alkalinity concentrations, mainly due to the coupling of plant growth and root respiration. But as expected from the concept of a maximum of growth-dependent $\mathrm{N}$

5 uptake and as empirically demonstrated in Figure 1a, alkalinity asymptotically approaches a maximum at elevated $\mathrm{NO}_{3}{ }^{-}$ concentrations. This result suggests that crop production is no longer limited by $\mathrm{N}$ when groundwater concentrations exceed approximately $0.25 \mathrm{mmol} \mathrm{NO}_{3}^{-} \mathrm{L}^{-1}$. The tolerance limit for drinking water $\left(0.4\right.$ and $0.7 \mathrm{mmol} \mathrm{NO}_{3}{ }^{-} \mathrm{L}^{-1}$ in Switzerland and USA, respectively) exceeds this value by approximately two- to three-fold. Accordingly, ecologically- and economicallyefficient agricultural practice avoiding over-fertilization with $\mathrm{N}$ (i.e., not exceeding $0.25 \mathrm{mmol} \mathrm{NO}_{3}^{-} \mathrm{L}^{-1}$ ) in no way is a risk

10 for a groundwater drinking-water supply.

Apart from these biological processes, the increase of $\mathrm{CO}_{2}$ oversaturation (Figure 1c) and the accompanying decrease in $\mathrm{pH}$ (Figure 1d) as $\mathrm{NO}_{3}{ }^{-}$concentration increases suggest that at least two physical-chemical processes might also contribute to the leveling-off of alkalinity at high $\mathrm{NO}_{3}{ }^{-}$concentrations. First, in a partly closed groundwater system, not all of the biogenic $\mathrm{CO}_{2}$ and protons are consumed by carbonate-dissolution reactions. $\mathrm{As}_{\mathrm{pCO}}$ increases and as $\mathrm{pH}$ concurrently decreases, the extent to which $\mathrm{H}_{2} \mathrm{CO}_{3}$ dissociates into $\mathrm{HCO}_{3}{ }^{-}$and $\mathrm{CO}_{3}{ }^{2-}$ decreases (because increasingly greater percentages of the DIC remain as $\mathrm{H}_{2} \mathrm{CO}_{3}$ as the $\mathrm{H}^{+}$concentration increases). Thereby, alkalinity increases at a decreasing rate as $\mathrm{pCO}_{2}$ increases. Second, as $\mathrm{pCO}_{2}$ increases in soil water, the rate of diffusive losses of $\mathrm{CO}_{2}$ through air channels in the soil increases. That tendency to diffusively lose $\mathrm{CO}_{2}$ to the atmosphere at increasingly faster rates slows the rate of alkalinity increase, as $\mathrm{NO}_{3}{ }^{-}$ concentration and associated biogenic $\mathrm{CO}_{2}$ production increase.

\subsubsection{Synthesis}

According to the compilation shown in Figure 2 for Switzerland, fertilization (including atmospheric deposition) of the soil contaminates groundwater with $1.52 \mathrm{kmol} \mathrm{N} \mathrm{ha}{ }^{-1} \mathrm{a}^{-1}$. This results in an average groundwater $\mathrm{NO}_{3}^{-}$concentration of 0.30 mmol L ${ }^{-1}$ and in a net-production of $2.36 \mathrm{kmol} \mathrm{H}^{+} \mathrm{ha}^{-1} \mathrm{a}^{-1}$ and $94.1 \mathrm{kmol} \mathrm{CO}_{2} \mathrm{ha}^{-1} \mathrm{a}^{-1}$. Subsequent equilibration of the 2.36 $\mathrm{kmol} \mathrm{H}^{+}$and $94.1 \mathrm{kmol} \mathrm{CO}_{2}$ in $5000 \mathrm{~m}^{3}$ water in contact with solid $\mathrm{CaCO}_{3}$ results in $\mathrm{pH} 7.14,5.56 \mathrm{mmol} \mathrm{L}^{-1}$ alkalinity and a $\mathrm{pCO}_{2}$ of $0.019 \mathrm{~atm}\left(1.1 \mathrm{mmol} \mathrm{L}^{-1}\right)$. These estimates (light blue circles in Figures 1a, c, d and e) agree well with the actual groundwater measurements.

Alternatively, assuming a scenario in which i) fields are neither fertilized nor harvested, ii) atmospheric deposition (currently $1.86 \mathrm{kmol} \mathrm{N} \mathrm{ha}^{-1} \mathrm{a}^{-1}$ ) is the only $\mathrm{N}$ source, and iii) denitrification removes the same fraction of $\mathrm{N}$ as in the fertilized scenario

30 (74\%), the resulting $\mathrm{NO}_{3}^{-}$loss via exfiltrating groundwater would be $0.48 \mathrm{kmol} \mathrm{N} \mathrm{ha}^{-1} \mathrm{a}^{-1}$ (i.e., a groundwater concentration of $0.097 \mathrm{mmol} \mathrm{NO}_{3}{ }^{-} \mathrm{L}^{-1}$ ). This value is 3.1 times lower than the fertilization scenario and is in the mid-rage of the minimum $\mathrm{NO}_{3}{ }^{-}$concentrations measured in Swiss groundwaters (Figure 1a). Assuming that the resulting production of $\mathrm{CO}_{2}$ and acidity as well as denitrification in the soil would be 3.1-fold lower than shown in Figure 2, the original groundwater concentrations would be $4.58 \mathrm{mmol} \mathrm{CO}_{2} \mathrm{~L}^{-1}$ and $0.23 \mathrm{mmol}$ acidity $\mathrm{L}^{-1}$ before reaction with soil carbonates. Equilibration with the soil carbonates would then result in an alkalinity of $3.30 \mathrm{mmol} \mathrm{L}^{-1}$, a pH of 7.54 , a $\Omega_{\mathrm{CO}_{2}}$ of 11.5 and a $\left[\mathrm{Ca}^{+2}\right] /\left[\mathrm{HCO}_{3}^{-}\right]$ratio of 0.54. These values, shown as light blue squares in Figures 1a, c, d, and e, also agree well with the observed data.

Finally, our dataset allows to assess the effect of Swiss farming practice on the atmospheric $\mathrm{CO}_{2}$ budget (Figure 3). As shown in Figure 2 (blue arrows), the soil is exposed to a total annual $\mathrm{CO}_{2}$ load of $94.1 \mathrm{kmol} \mathrm{CO}_{2} \mathrm{ha}^{-1} \mathrm{a}^{-1}$. Because $\mathrm{CO}_{2}$ neither accumulates infinitely nor is assimilated in soils, it must leave the aquifer as gaseous $\mathrm{CO}_{2}$ or dissolved in the exfiltrating groundwater either as $\mathrm{H}_{2} \mathrm{CO}_{3}{ }^{*}\left(=\mathrm{H}_{2} \mathrm{CO}_{3}+\mathrm{CO}_{2}\right.$ (aqueous)) or as dissolved $\mathrm{Ca}\left(\mathrm{HCO}_{3}\right)_{2}$. In the 47 -fold supersaturated groundwater, the $\mathrm{H}_{2} \mathrm{CO}_{3}{ }^{*}$ concentration equals $1.1 \mathrm{~mol} \mathrm{~m}^{-3}$. Multiplication with the volume of the annually exfiltrating groundwater $\left(5000 \mathrm{~m}^{3} \mathrm{ha}^{-1} \mathrm{a}^{-1}\right)$ results in $\mathrm{H}_{2} \mathrm{CO}_{3}{ }^{*}$ export of $5.5 \mathrm{kmol} \mathrm{ha}^{-1} \mathrm{a}^{-1}$. 
Biogeosciences Discuss., https://doi.org/10.5194/bg-2018-461

Manuscript under review for journal Biogeosciences

Discussion started: 6 November 2018

(c) Author(s) 2018. CC BY 4.0 License.

In addition, $27.8 \mathrm{kmol} \mathrm{ha}^{-1} \mathrm{a}^{-1}$ of alkalinity is exported with the groundwater. This is partly due to the $2.36 \mathrm{kmol} \mathrm{H}^{+} \mathrm{ha}^{-1} \mathrm{a}^{-1}$ introduced to the system, which generates an equal amount of alkalinity by dissolution of carbonates (Equation 2). However, the remaining $25.44 \mathrm{kmol} \mathrm{ha}^{-1} \mathrm{a}^{-1}$ of exported alkalinity must have resulted from the reaction of $12.72 \mathrm{kmol} \mathrm{ha}^{-1} \mathrm{a}^{-1}$ of $\mathrm{CO}_{2}$ (predominantly present as $\mathrm{H}_{2} \mathrm{CO}_{3}$ in the water) with carbonates (Equation 3). Subtracting the sum of these two $\mathrm{CO}_{2}$ losses

5 via groundwater $\left(5.5+12.72=18.22 \mathrm{kmol} \mathrm{ha}^{-1} \mathrm{a}^{-1}\right)$ from the total $\mathrm{CO}_{2}$ exposure $\left(94.1 \mathrm{kmol} \mathrm{CO}_{2} \mathrm{ha}^{-1} \mathrm{a}^{-1}\right)$ results in a gaseous $\mathrm{CO}_{2}$ loss to the atmosphere of $75.9 \mathrm{kmol} \mathrm{CO}_{2} \mathrm{ha}^{-1} \mathrm{a}^{-1}$.

On the other hand, crop production extracts $10.6 \mathrm{kmol} \mathrm{N} \mathrm{ha}^{-1} \mathrm{a}^{-1}$ from the soil, corresponding to a $70.2 \mathrm{kmol} \mathrm{CO}_{2} \mathrm{ha}^{-1} \mathrm{a}^{-1}$ net consumption from the atmosphere. Consequently, Swiss agricultural activities burden the atmosphere annually with $5.7 \mathrm{kmol}$ $\mathrm{CO}_{2} \mathrm{ha}^{-1} \mathrm{a}^{-1}$. Extrapolation to the total Swiss agricultural area yields an annual accumulation of $0.26 \mathrm{MtCO}_{2} \mathrm{a}^{-1}$. This is a

10 very conservative estimate, because it neglects the $\mathrm{CO}_{2}$ emissions from $\mathrm{CO}_{2}$-supersaturated surface waters and does not consider that a large fraction of the harvest serves as food for animals, which generate additional $\mathrm{CO}_{2}$.

\subsection{Surface Waters}

Although groundwater exfiltrates to riverbeds or lakes, surface-water quality is in addition subjected to surface runoff and wastewater discharges.

15 When $\mathrm{CO}_{2}$-supersaturated groundwater exfiltrates and becomes surface water, much of the above-saturation $\mathrm{CO}_{2}$ diffuses into the atmosphere. Additionally, photoautotrophic organisms may assimilate some of the $\mathrm{CO}_{2}$. Both processes lead to the observed higher $\mathrm{pH}$ and lower $\Omega_{\mathrm{CO}_{2}}$ values in rivers and lakes than in groundwaters at similar $\mathrm{NO}_{3}{ }^{-}$concentrations (Figures 1c and d). Nevertheless, $\mathrm{CO}_{2}$ concentrations in the river and lake waters did not reach equilibrium with the atmospheric $\mathrm{pCO}_{2}$, possibly because of heterotrophic mineralization and slow diffusional loss of the $\mathrm{CO}_{2}$ to the atmosphere (Hotchkiss et

20 al., 2015).

Calcite would be expected to precipitate due to the loss of $\mathrm{CO}_{2}$ and the rising $\mathrm{pH}$ when groundwater exfiltrates. However, as demonstrated in Figure 1g, it remains oversaturated in surface waters, indicating that precipitation of calcite often is kinetically constrained (Plummer et al., 1979) and/or at least partly inhibited (e.g., by elevated phosphate concentrations; Langmuir, 1997: p. 222; Müller et al., 2016).

25 Wastewater loads to a river may alter its groundwater-derived alkalinity- $\mathrm{NO}_{3}^{-}$relationship in several ways. First, introduction of $\mathrm{NH}_{4}{ }^{+}$-containing wastewater into well-oxygenated river water results in nitrification that increases the $\mathrm{NO}_{3}{ }^{-}$ concentration but simultaneously decreases the $\mathrm{pH}$ and alkalinity if carbonate minerals are not present (Equation S-1 in SI Table S1) or do not dissolve fast enough, thus contributing to an additional release of $\mathrm{CO}_{2}$ to the atmosphere. Second, the introduction of large amounts of wastewater-derived dissolved organic matter stimulates microbial respiration, resulting in

30 low $\mathrm{O}_{2}$ concentrations that favor denitrification and/or dissimilatory $\mathrm{NO}_{3}{ }^{-}$reduction to ammonia, both of which decrease $\mathrm{NO}_{3}{ }^{-}$concentrations but increase alkalinity even in the absence of carbonate minerals (Equations S-10 to S-12 in SI Table $\mathrm{S} 1)$.

Consequently, as demonstrated by Abril et al. (2000) and Abril and Frankignoulle (2001) in the highly-polluted Scheldt Basin (Belgium and Netherlands), large wastewater loads can induce $\mathrm{N}$ transformations in river water and change its acid-

35 base properties to the extent that the positive relationship between alkalinity and $\mathrm{NO}_{3}{ }^{-}$concentration observed in calcareous soils completely reverses in a river. Although that reversal did not occur in the Swiss surface waters, a trend toward lower alkalinity at a given $\mathrm{NO}_{3}{ }^{-}$concentration is apparent (Figure 1b). 
Biogeosciences Discuss., https://doi.org/10.5194/bg-2018-461

Manuscript under review for journal Biogeosciences

Discussion started: 6 November 2018

(c) Author(s) 2018. CC BY 4.0 License.

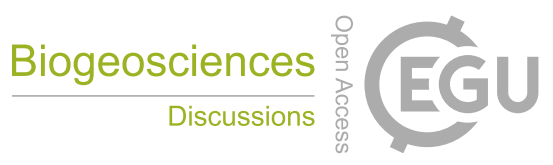

(c) (i)

\section{Conclusions}

As illustrated in Figure 2 and discussed above, N-limited terrestrial primary production plays a dominant role in the linking of alkalinity and $\mathrm{NO}_{3}{ }^{-}$concentrations in aquifer and surface waters. From a global perspective, application of N-fertilizers fueling the production of short-lived organic matter contributes to a net increase of atmospheric $\mathrm{CO}_{2}$ concentrations via

5 release of $\mathrm{CO}_{2}$ that otherwise would remain sequestered in carbonate minerals in soils (West and McBride, 2005; Perrin et al., 2008; Li et al., 2013), and accelerates the translocation of DIC from calcareous soils to downstream reaches in surface waterways and eventually to the oceans.

As atmospheric $\mathrm{CO}_{2}$ concentrations increase and thus riverine, lake, and oceanic $\mathrm{pH}$ values decrease through time, the proportion of the DIC that precipitates as $\mathrm{CaCO}_{3}$ after $\mathrm{CO}_{2}$-oversaturated aquifer waters ex-filtrate to surface-water bodies

10 will decrease, and the proportion that is released to the atmosphere as $\mathrm{CO}_{2}$ will increase. Therefore, continued N-fertilization will contribute to the ongoing global $\mathrm{CO}_{2}$ enrichment of the atmosphere and will promote in-soil calcite dissolution. 
Biogeosciences Discuss., https://doi.org/10.5194/bg-2018-461

Manuscript under review for journal Biogeosciences

Discussion started: 6 November 2018

(c) Author(s) 2018. CC BY 4.0 License.

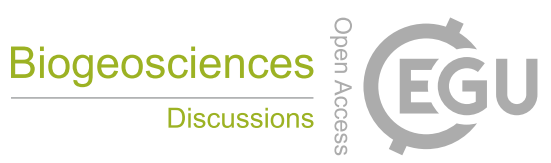

(c) (i)

\section{Information about the Supplement}

Table S-1 lists chemical reactions for the nitrification of some common N-fertilizers and several other processes in groundwaters and surface waters in the presence and absence of carbonate minerals. Table S-2 reports results of regressions of alkalinity versus $\mathrm{NO}_{3}{ }^{-}$concentration in Swiss groundwaters, Canton Zürich well waters, and Swiss lakes and rivers.

Author contributions. BM, JSM, and RG contributed equally to the manuscript. BM performed ChemEQL speciation calculations.

Competing interests. The authors declare that they have no conflict of interest.

10

Acknowledgements. Financial support was provided by Eawag (Switzerland) and Applied Limnology Professionals LLC. Groundwater data from the Canton of Zürich were provided by the Office of Waste, Water, Energy and Air (WWEA) of the Canton of Zürich, Switzerland. Data of the National Groundwater Monitoring program (NAQUA), module 'TREND', were provided by the Swiss Federal Office for the Environment (FOEN).

15 
Biogeosciences Discuss., https://doi.org/10.5194/bg-2018-461

Manuscript under review for journal Biogeosciences

Discussion started: 6 November 2018

(c) Author(s) 2018. CC BY 4.0 License.

\section{References}

Abril, G., Etcheber, H., Borges, A. V., and Frankignoulle, M.: Excess atmospheric carbon dioxide transported by rivers into the Scheldt estuary. Earth Planet. Sci., 330, 761-768, https://doi.org/10.1016/S1251-8050(00)00231-7, 2000.

Abril, G., and Frankignoulle, M.: Nitrogen-alkalinity interactions in the highly polluted Scheldt Basin (Belgium). Water

5 Res., 35, 844-850, https://doi.org/10.1016/S0043-1354(00)00310-9, 2001.

AWEL (Canton Zürich Office of Waste, Water, Energy and Air): Groundwater quality, http://www.awel.zh.ch/internet/baudirektion/awel/de/wasser/messdaten.html, 2017.

BAFU (Swiss Federal Office for the Environment): National long-term surveillance of Swiss lakes (on request), https://www.bafu.admin.ch/bafu/en/home/state/data/geodata.html, 2017.

10 Barnes, R. T., and Raymond, P. A.: The contribution of agricultural and urban activities to inorganic carbon fluxes within temperate watersheds. Chem. Geol., 266, 327-336, https://doi.org/10.1016/j.chemgeo.2009.06.018, 2009.

Battye, W., Aneja, V. P., and Schlesinger, W. H.: Is nitrogen the next carbon? Earth's Future, 5, 894-904, https://doi.org/10.1002/2017EF000592, 2017.

Baule, B.: Mitscherlich's law of physiological relations (in German). Landwirtschaftl. Jahrbücher, 51, 363-385, 1917.

15 Brunet, F., Potot, C., Probst, A., and Probst, J.-L.: Stable carbon isotope evidence for nitrogenous fertilizer impact on carbonate weathering in a small agricultural watershed. Rapid Commun. Mass Sp., 25, 2682-2690,

https://doi.org/10.1002/rcm.5050, 2011.

Cheng, W. X., Sims, D. A., Luo, Y. Q., Coleman, J. S., and Johnson, D. W.: Photosynthesis, respiration, and net primary production of sunflower stands in ambient and elevated atmospheric CO2 concentrations: an invariant NPP:GPP ratio?

Global Change Biol., 6, 931-941, https://doi.org/10.1046/j.1365-2486.2000.00367.x, 2000.

Eawag (Swiss Federal Institute of Aquatic Science and Technology): National long-term surveillance of Swiss rivers (NADUF), http://www.eawag.ch/en/department/wut/main-focus/chemistry-of-water-resources/naduf/, 2017.

FOAG: Federal Office for Agriculture. Marktbericht Mineraldünger, Januar 2016.

https://www.blw.admin.ch/blw/de/home/markt/marktbeobachtung/duenger.html, 2016.

25 FOAG: Federal Office for Agriculture. Agrarbericht 2017.

https://www.blw.admin.ch/blw/de/home/services/agrarbericht.html.

https://www.agrarbericht.ch/de/betrieb/strukturen/landwirtschaftliche-nutzflaeche, 2018.

FOMC: Federal Office of Meteorology and Climatology MeteoSwiss.

https://www.meteoswiss.admin.ch/home/climate/swiss-climate-in-detail/climate-normals/normal-values-per-measured-

30 parameter.html, 2018.

FSO: Nitrogen and phosphorus: Nutrients or pollutants? The nitrogen and phosphorus balance of Swiss agriculture. https://www.bfs.admin.ch/bfsstatic/dam/assets/349334/master. Federal statistical office FSO, BFS no. 1165-1400, Neuchatel, August 2014.

Guo, J. H., Liu, X. J., Zhang, Y., Shen, J. L., Han, W. X., Zhang, W. F., Christie, P., Goulding K. W. T., Vitousek, P. M.,

and Zhang, F. S.: Significant acidification in major Chinese croplands. Science, 327, 1008-1010,

https://doi.org/10.1126/science.1182570, 2010.

Graf Pannatier, E., Thimonier, A., Schmitt, M., Walthert, L., and Waldner P.: A decade of monitoring at Swiss Long-Term Forest Ecosystem Research (LWF) sites: can we observe trends in atmospheric acid deposition and in soil solution acidity? Environ Monit Assess. 174, 3-30, https://doi.org/10.1007/s10661-010-1754-3, 2011.

40 GSchG: Swiss law for the protection of the environment, Art. 14 Abs. 4 GSchG, https://www.admin.ch/opc/de/classifiedcompilation/19910022/201701010000/814.20.pdf, 2017.

Haynes, R. J.: Active ion uptake and maintenance of cation-anion balance: A critical examination of their role in regulating rhizosphere pH. Plant Soil, 126, 247-264, https://doi.org/10.1007/BF00012828, 1990. 
Biogeosciences Discuss., https://doi.org/10.5194/bg-2018-461

Manuscript under review for journal Biogeosciences

Discussion started: 6 November 2018

(c) Author(s) 2018. CC BY 4.0 License.

Hotchkiss, E. A., Hall Jr, R. O., Sponseller, R. A., Butman, D., Klaminder, J., Laudon, H., Rosvall, M., and Karlsson, J.: Sources of and processes controlling $\mathrm{CO}_{2}$ emissions change with the size of streams and rivers. Nature Geosci., 8, 696-699, https://doi.org/10.1038/NGEO2507, 2015.

Hürdler, J., Prasuhn, V., and Spiess, E. Abschätzung diffuser Stickstoff- und Phosphoreinträge in die Gewässer der Schweiz

5 MODIFFU 3.0. Report to the hands of the Swiss Federal Office for the Environment, FOEN. Agroscope, July 2015 (in German).

https:/www.agroscope.admin.ch/dam/agroscope/de/dokumente/themen/umwelt-ressourcen/gewaesserschutz/huerdlerprasuhn-spiess-endbericht-modiffus.pdf.download.pdf/Hürdler_Prasuhn_Spiess_2015_Endbericht_MODIFFUS.pdf

Kaushal, S. S., Likens, G. E., Utz, R. M., Pace, M. L., Grese, M., and Yepsen, M.: Increased river alkalinization in the

10 Eastern U.S. Environ. Sci. Technol., 47, 10302-10311, https://doi.org/10.1021/es401046s, 2013.

Langmuir, D.: Aqueous environmental geochemistry. Prentice-Hall, Inc. Upper Saddle River, New Jersey, USA, 1997.

Li, S., Lu, X. X., and Bush, R. T.: $\mathrm{CO}_{2}$ partial pressure and $\mathrm{CO}_{2}$ emission in the Lower Mekong River. J. Hydrol., 504, 4056, https://doi.org/10.1016/i.jhydrol.2013.09.024, 2013.

Müller, B.: ChemEQL V3.2: A program to calculate chemical speciation equilibria, titrations, dissolution, precipitation, adsorption, kinetics, pX-pY diagrams, solubility diagrams. Eawag: Swiss Federal Institute of Aquatic Science and Technology, Kastanienbaum, Switzerland, http://www.eawag.ch/en/department/surf/projects/chemeq1/, 2015.

Müller, B., Meyer, J. S., and Gächter, R.: Alkalinity regulation in calcium carbonate-buffered lakes. Limnol. Oceanogr., 61, 341-352, https://doi.org/10.1002/lno.10213, 2016.

NABEL (Nationales Beobachtungsnetz für Luftfremdstoffe (NABEL). Swiss Federal Office for the Environment (FOEN), http://www.bafu.admin.ch/uz-1624-d, Bern, 2016.

NAQUA (National groundwater monitoring of Switzerland): Module ,TREND'. Swiss Federal Office for the Environment (FOEN), on request, 2017.

NOAA (National Oceanic and Atmospheric Administration): Trends in atmospheric carbon dioxide: Mauna Loa $\mathrm{CO}_{2}$ annual mean data, http://www.esrl.noaa.gov/gmd/ccgg/trends/co2/co2_annmean_mlo.txt, 2017.

25 Oh, N.-H., and Raymond, P. A.: Contribution of agricultural liming to riverine bicarbonate export and $\mathrm{CO}_{2}$ sequestration in the Ohio River basin. Glob. Biogeochem. Cycles, 20. GB3012, https://doi.org/10.1029/2005GB002565, 2006.

Perrin, A.-S., Probst, A., and Probst, J.-L.: Impact of nitrogenous fertilizers on carbonate dissolution in small agricultural catchments: Implications for weathering $\mathrm{CO}_{2}$ uptake at regional and global scales. Geochim. Cosmochim. Acta, 72, 31053123, https://doi.org/10.1016/j.gca.2008.04.011, 2008.

30 Plummer, L. N., Parkhurst, D. L., and Wigley, T. M. L.: Critical review of the kinetics of calcite dissolution and precipitation. Pp. 537-573 in: Jenne E. A. (ed.), Chemical Modeling in Aqueous Systems: Speciation, Sorption, Solubility, and Kinetics, ACS Symposium Series 93, 1979, American Chemical Society, Washington, District of Columbia, USA.

Probst, J.-L.: Dissolved and suspended matter transported by the Girou River (France): Mechanical and chemical erosion rates in a calcareous molasse basin. Hydrolog. Sci. J., 31, 61-79, https://doi.org/10.1080/02626668609491028, 1986.

35 Raich, J. W., and Tufekcioglu, A.: Vegetation and soil respiration: Correlation and controls. Biogeochem., 48, 71-90, https://doi.org/10.1023/A:1006112000616, 2000.

Raymond, P. A., and Cole, J. J.: Increase in the export of alkalinity from North America's largest river. Science, 301, 88-91, https://doi.org/10.1126/science.1083788, 2003.

Raymond, P. A., Oh, N.-H., Turner, R. E., and Broussard W.: Anthropogenically enhanced fluxes of water and carbon from

the Mississippi River. Nature, 451, 449-452, https://doi.org/10.1038/nature06505, 2008.

Semhi, K., Suchet, P. A., Clauer, N., and Probst, J.-L.: Impact of nitrogen fertilizers on the natural weathering-erosion processes and fluvial transport in the Garonne basin. Appl. Geochem., 15, 865-878, https://doi.org/10.1016/S08832927(99)00076-1, 2000. 
Biogeosciences Discuss., https://doi.org/10.5194/bg-2018-461

Manuscript under review for journal Biogeosciences

Discussion started: 6 November 2018

(c) Author(s) 2018. CC BY 4.0 License.

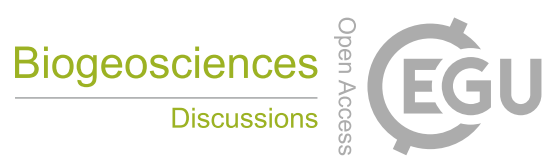

(c) $\underset{\mathrm{BY}}{(i)}$

Stumm, W., and Morgan, J. J.: Aquatic Chemistry. $3^{\text {rd }}$ Ed. John Wiley \& Sons, Inc., New York, New York, USA, 1996.

Walworth, J.: Nitrogen in soil and the environment. Cooperate Extension Publication AZ1591, University of Arizona,

Tucson, Arizona, USA. 3 pages, 2013.

West, T. O., and McBride, A. C.: The contribution of agricultural lime to carbon dioxide emissions in the United States:

5 Dissolution, transport, and net emissions. Agric. Ecosyst. Environ., 108, 145-154,

https://doi.org/10.1016/j.agee.2005.01.002, 2005.

Zobrist, J., Schoenenberger, U., Figura, S., and Hug, S. J.: Long-term trends in Swiss rivers sampled continuously over 39 years reflect changes in geochemical processes and pollution. Environ. Sci. Poll. Res., https://doi.org/10.1007/s11356-0181679-x. 2018.

10 
Biogeosciences Discuss., https://doi.org/10.5194/bg-2018-461

Manuscript under review for journal Biogeosciences

Discussion started: 6 November 2018

(c) Author(s) 2018. CC BY 4.0 License.

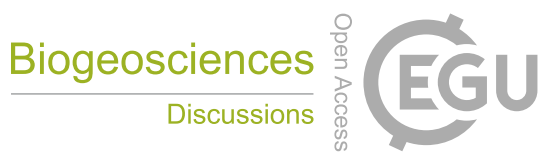

(c) (i)

Table 1: Data sources.

\begin{tabular}{|c|c|c|c|}
\hline Dataset & Description & $\begin{array}{c}\text { Range of } \\
\mathrm{NO}_{3}^{-} \\
\left(\mathrm{mmol} \mathrm{L}^{-1}\right)\end{array}$ & $\begin{array}{l}\text { Range of } \\
\text { alkalinity } \\
\left(\mathrm{mmol} \mathrm{L}^{-1}\right)\end{array}$ \\
\hline Aquifers & 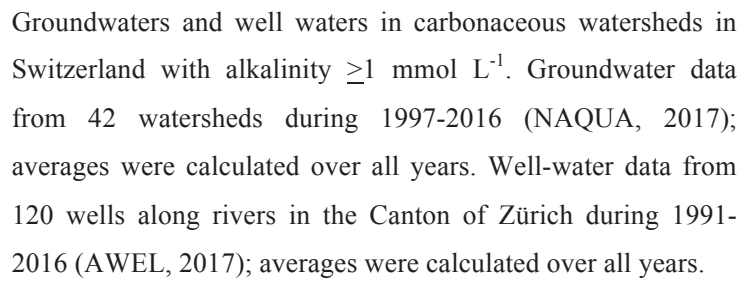 & $\begin{array}{c}0.004- \\
0.905\end{array}$ & $2.08-7.88$ \\
\hline $\begin{array}{l}\text { Surface } \\
\text { waters }\end{array}$ & $\begin{array}{l}\text { Lake and river waters in carbonaceous watersheds in } \\
\text { Switzerland with alkalinity } \geq 1 \mathrm{mmol} \mathrm{\textrm {L } ^ { - 1 }} \text {. Lake data from } 21 \\
\text { lakes (0.2-580) } \mathrm{km}^{2} \text { during } 1980-2015 \text { (BAFU, 2017); based on } \\
\text { volume-weighted mean concentrations at winter/spring lake } \\
\text { overturn averaged over all years. Only } 16 \text { of the lakes had Ca } \\
\text { and Mg data. River data from } 22 \text { stations on } 12 \text { rivers during 5- } \\
\text { to } 44 \text {-year monitoring periods (Eawag, 2017); based on } \\
\text { concentrations at lake overturn averaged across all years. }\end{array}$ & $\begin{array}{c}0.017- \\
0.219\end{array}$ & $1.52-5.03$ \\
\hline
\end{tabular}


Biogeosciences Discuss., https://doi.org/10.5194/bg-2018-461

Manuscript under review for journal Biogeosciences

Discussion started: 6 November 2018

(c) Author(s) 2018. CC BY 4.0 License.

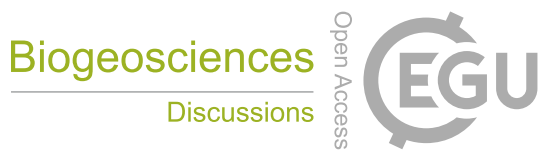

(c) (i)

Table 2: Regressions of alkalinity versus nitrate $\left(\mathrm{NO}_{3}{ }^{-}\right)$concentration for the Swiss aquifer and surface-water data in Figure $1 .{ }^{\mathrm{a}}$

\begin{tabular}{|c|c|c|c|c|c|c|c|}
\hline \multirow[b]{2}{*}{ Waters } & \multirow[b]{2}{*}{$\begin{array}{c}\mathrm{NO}_{3}^{-} \text {range } \\
\text { for regression } \\
\left(\mathrm{mmol} \mathrm{L}^{-1}\right)\end{array}$} & \multicolumn{2}{|c|}{ Slope } & \multicolumn{2}{|c|}{ Intercept } & \multirow[b]{2}{*}{$\begin{array}{c}\text { Regression } \\
\mathrm{R}^{2}\end{array}$} & \multirow[b]{2}{*}{$\mathrm{n}$} \\
\hline & & $\begin{array}{c}\text { Value } \\
(\mathrm{mmol} \mathrm{Alk} / \\
\left.\mathrm{mmol} \mathrm{NO}_{3}^{-}\right)\end{array}$ & $\mathrm{p}$ & $\begin{array}{c}\text { Value } \\
\left(\mathrm{mmol} \mathrm{L}^{-1}\right)\end{array}$ & $\mathrm{p}$ & & \\
\hline \multirow[b]{2}{*}{ Aquifers } & $<0.25$ & $\begin{array}{c}17.04 \\
(13.89-20.19)\end{array}$ & $<0.001$ & $\begin{array}{c}2.44 \\
(1.95-2.93)\end{array}$ & $<0.001$ & 0.681 & 57 \\
\hline & $>0.25$ & $\begin{array}{c}1.79 \\
(0.72-2.86)\end{array}$ & 0.001 & $\begin{array}{c}5.62 \\
(5.15-6.09)\end{array}$ & $<0.001$ & 0.097 & 105 \\
\hline $\begin{array}{l}\text { Surface } \\
\text { waters }^{\mathrm{b}}\end{array}$ & $<0.25$ & $\begin{array}{c}12.48 \\
(9.67-15.29)\end{array}$ & $<0.001$ & $\begin{array}{c}1.74 \\
(1.48-2.00)\end{array}$ & $<0.001$ & 0.662 & 43 \\
\hline
\end{tabular}

5

a $95 \%$ confidence intervals of slopes and intercepts are in parentheses; "p" is the probability value of the slope or intercept being equal to 0 (i.e., $\mathrm{p}<0.05$ indicates significant difference from zero); Alk = alkalinity.

b None of the surface waters had an $\mathrm{NO}_{3}{ }^{-}$concentration $>0.25 \mathrm{mmol} \mathrm{L}^{-1}$.

10 
Biogeosciences Discuss., https://doi.org/10.5194/bg-2018-461

Manuscript under review for journal Biogeosciences

Discussion started: 6 November 2018

(c) Author(s) 2018. CC BY 4.0 License.

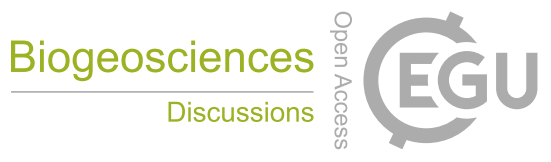

(c) (i)

Table 3: Averaged nitrogen budget for agricultural soils (10’490 km²) in Switzerland. (FOAG, 2018).

\begin{tabular}{|c|c|c|}
\hline Input/output & $\begin{array}{l}\text { annual } \mathbf{N} \text { flux } \\
\mathrm{kg} \mathrm{N} \mathrm{ha}^{-1} \mathrm{a}^{-1}\end{array}$ & reference \\
\hline Total N supply & 233 & FSO (2014) \\
\hline Fertilizer supply & 206 & FSO (2014) \\
\hline Manure & 124 & FSO (2014) \\
\hline Leguminosae & 32 & FSO (2014) \\
\hline Org/inorg commercial fertilizer & 50 & FSO (2014) \\
\hline $\mathrm{NH}_{4} \mathrm{NO}_{3}(60 \%)$ & 30 & FOAG (2016) \\
\hline Urea $(20 \%)$ & 10 & FOAG (2016) \\
\hline Other $(20 \%)$ & 10 & FOAG (2016) \\
\hline $\mathrm{N}$ deposition with seeds & 1 & FSO (2014) \\
\hline Atmospheric $\mathbf{N}$ deposition & 26 & FSO (2014) \\
\hline Atm. $\mathrm{NO}_{3}^{-}$deposition & 8.7 & \\
\hline Atm. $\mathrm{NH}_{4}^{+}$deposition & 17.3 & \\
\hline Nitrogen removal with crop & 148 & FSO (2014) \\
\hline Excess nitrogen deposition & 85 & FSO (2014) \\
\hline $\mathrm{N}$ removal by groundwater to surface waters & 22 & Hürdler et al. (2015a) \\
\hline $\begin{array}{l}\mathrm{N} \text { load to the atmosphere by denitrification } \\
\text { to } \mathrm{N}_{2} \text { and/or } \mathrm{N}_{2} \mathrm{O}\end{array}$ & 63 & \\
\hline
\end{tabular}

5 
Biogeosciences Discuss., https://doi.org/10.5194/bg-2018-461

Manuscript under review for journal Biogeosciences

Discussion started: 6 November 2018

(c) Author(s) 2018. CC BY 4.0 License.

(c) (1)

Figure 1:
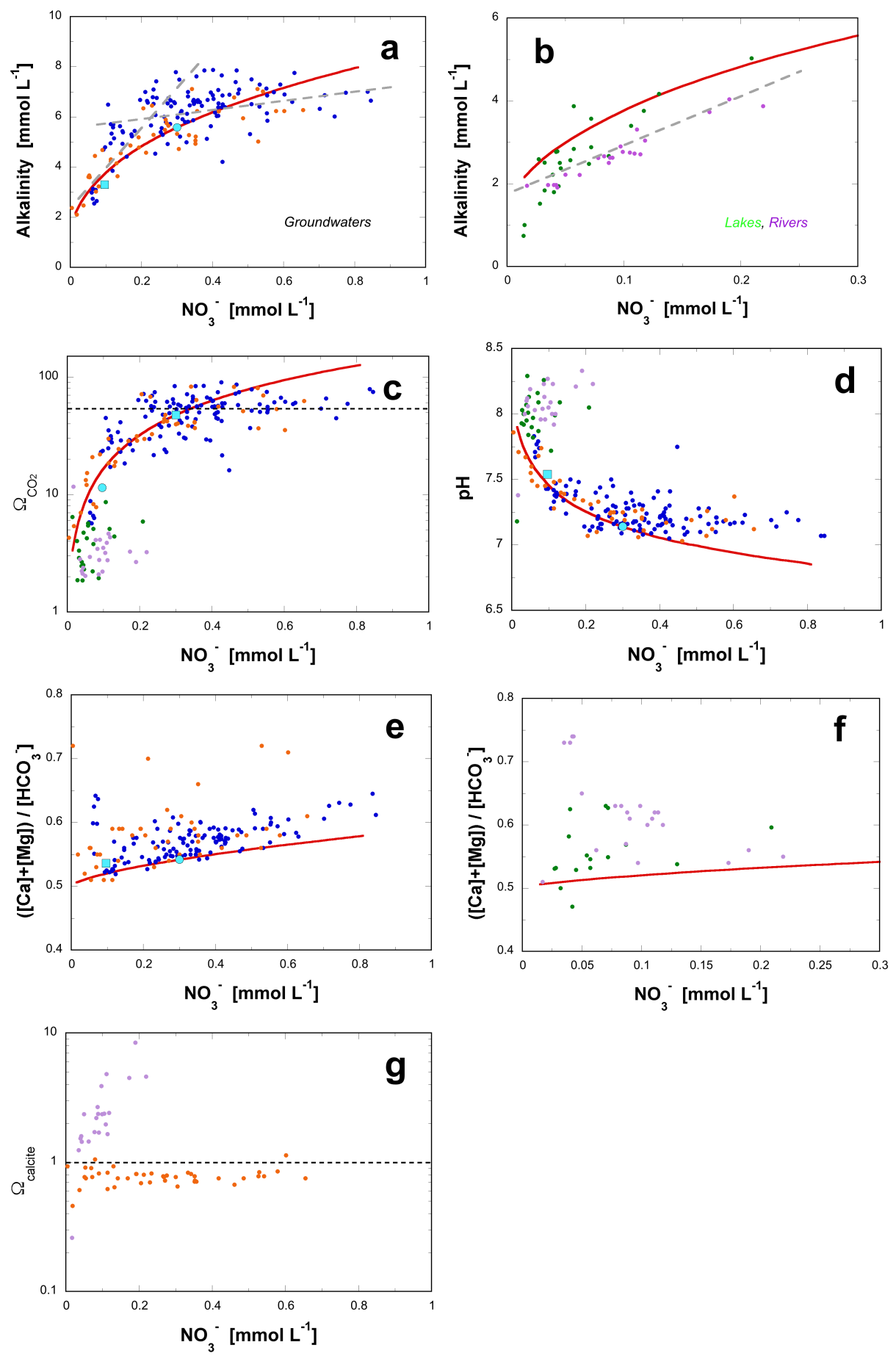
Biogeosciences Discuss., https://doi.org/10.5194/bg-2018-461

Manuscript under review for journal Biogeosciences

Discussion started: 6 November 2018

(c) Author(s) 2018. CC BY 4.0 License.

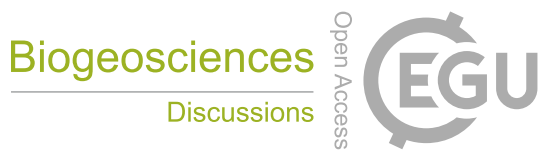

(c) $\underset{\mathrm{BY}}{(i)}$

Figure 1: Relationships between $\mathrm{NO}_{3}{ }^{-}$concentration and (a and b) alkalinity, (c) $\Omega_{\mathrm{CO}_{2}}\left(\mathrm{CO}_{2}\right.$ saturation index), (d) $\mathrm{pH}$, (e and f) molar $([\mathrm{Ca}]+[\mathrm{Mg}]) /\left[\mathrm{HCO}_{3}{ }^{-}\right]$ratio, and $(\mathrm{g}) \Omega_{\text {calcite }}$ (calcite $\left[\mathrm{CaCO}_{3}\right]$ saturation index) in aquifers and surface waters in calcareous catchments in Switzerland that had alkalinity $\geq 1 \mathrm{mmol} \mathrm{L}^{-1}$. These include 42 groundwaters across the country (orange), 120 wells in the Canton of Zürich (blue), 21 lakes (green), and 22 stations on 12 rivers (purple) (Table 1). The light

5 blue circle depicts the resulting alkalinity for the estimated average loads of $1.52 \mathrm{kmol} \mathrm{N} \mathrm{ha}^{-1} \mathrm{a}^{-1}, 2.36 \mathrm{kmol} \mathrm{H}^{+} \mathrm{ha}^{-1} \mathrm{a}^{-1}$ and $94.1 \mathrm{kmol} \mathrm{CO}_{2} \mathrm{ha}^{-1} \mathrm{a}^{-1}$ (see Synthesis section) and a groundwater formation rate of $5000 \mathrm{~m}^{3} \mathrm{ha}^{-1} \mathrm{a}^{-1}$. The solid red curve is the ChemEQL-predicted relationship assuming the $\mathrm{NO}_{3}{ }^{-}: \mathrm{CO}_{2}: \mathrm{H}^{+}$ratio of the above loads in a system open to the air in the soil in the presence of calcite. The light blue square depicts the alkalinity and $\mathrm{NO}_{3}{ }^{-}$concentration in a natural system without fertilization and without crop harvest, but with the current atmospheric $\mathrm{N}$ deposition of $1.86 \mathrm{kmol} \mathrm{ha}^{-1} \mathrm{a}^{-1}$. The speciation

10 calculation was performed considering the activities of the ions (Debye-Hückel-approximation), which was essential for the appropriate estimation of the dissolution of calcite. Note the difference in scale for the horizontal axis between panels b) and f) and the other five panels. Linear-regression slopes and intercepts shown by the black lines in panels a) and b) are listed in Table 2. 
Biogeosciences Discuss., https://doi.org/10.5194/bg-2018-461

Manuscript under review for journal Biogeosciences

Discussion started: 6 November 2018

(c) Author(s) 2018. CC BY 4.0 License.

\section{(c) (1)}
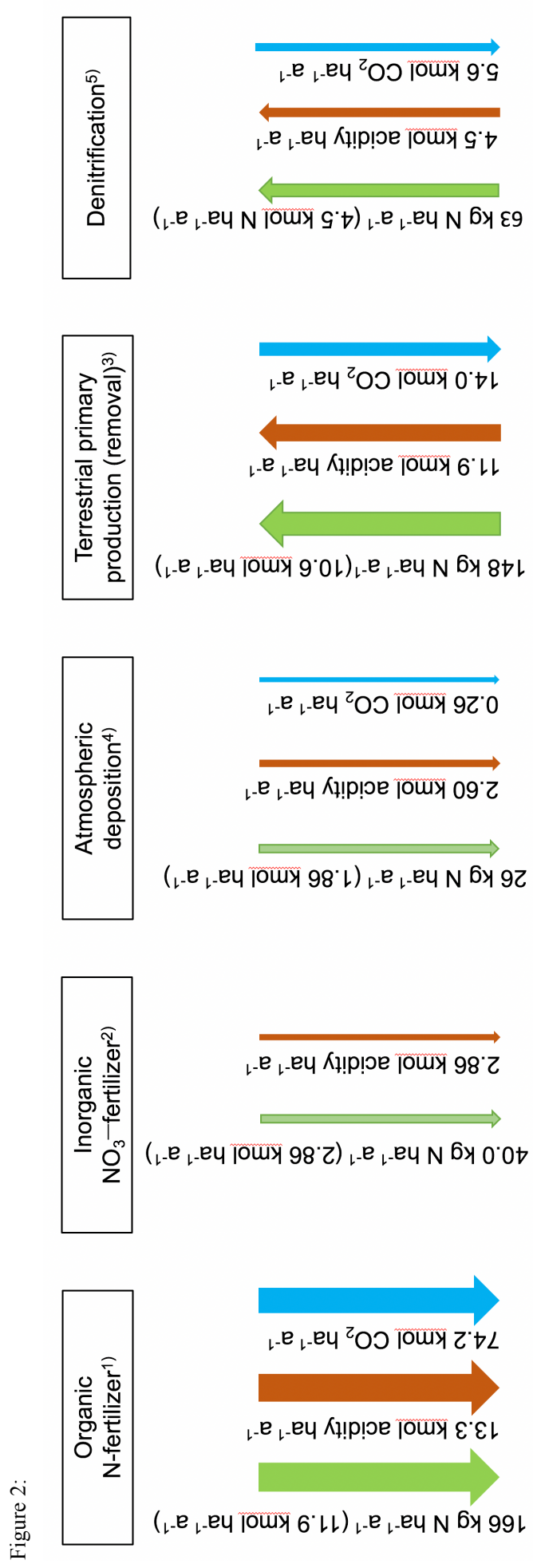

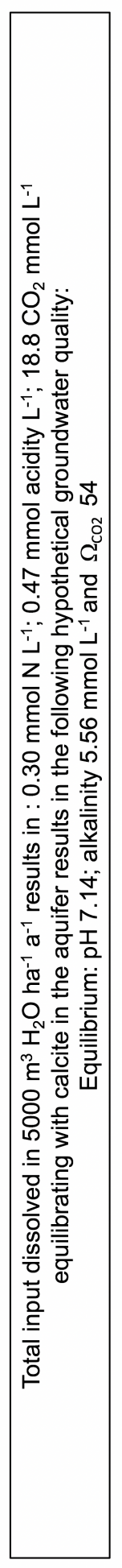


Biogeosciences Discuss., https://doi.org/10.5194/bg-2018-461

Manuscript under review for journal Biogeosciences

Discussion started: 6 November 2018

(c) Author(s) 2018. CC BY 4.0 License.

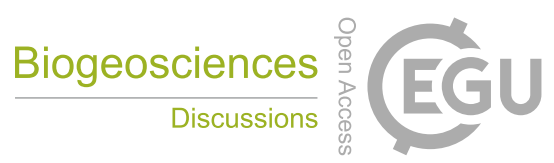

(c) (i)

Figure 3:

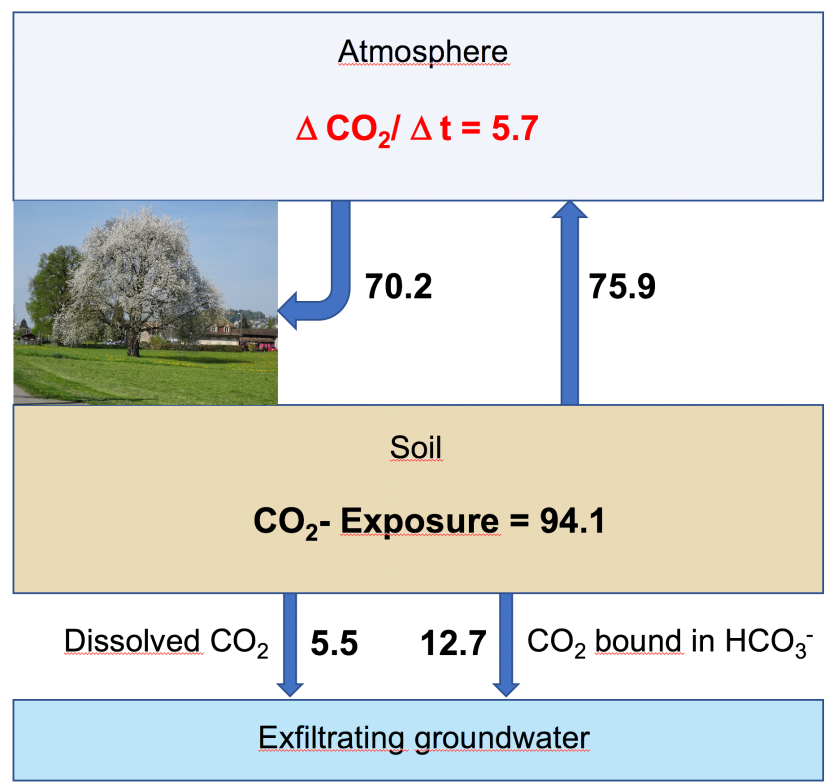

Figure 3: $\mathrm{CO}_{2}$ budget of Swiss agricultural soils. Fluxes in $\mathrm{kmol} \mathrm{CO}_{2} \mathrm{ha}^{-1} \mathrm{a}^{-1}$. 